\begin{tabular}{|c|c|c|}
\hline$\underset{P \cup B L I C A T I O N}{\operatorname{NF}}$ & $\begin{array}{l}\text { International Journal of Advanced Engineering, Management and Science } \\
\text { (IJAEMS) } \\
\text { ISSN: 2454-1311 } \\
\text { Vol-7, Issue-3; Mar, } 2021 \\
\text { Journal Home Page Available: } \underline{\text { https://ijaems.com/ }} \\
\text { Journal DOI: } \text { https://dx.doi.org/10.22161/ijaems } \\
\text { Article DOI: https://dx.doi.org/10.22161/ijaems.73.3 }\end{array}$ & 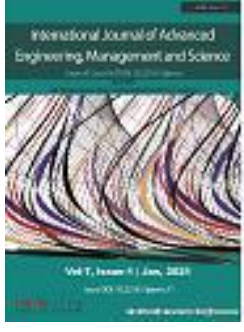 \\
\hline
\end{tabular}

\title{
Social Media Exposure of Students in Relation to Academic Performance
}

\author{
Grazl T. Baria, EdD
}

Teacher Education Department, Capiz State University - Dayao Satellite College, Philippines

Received: 09 Dec 2020; Received in revised form: 03 Feb 2021; Accepted: 21 Feb 2021; Available online: 10 Mar 2021

(C)2021 The Author(s). Published by Infogain Publication. This is an open access article under the CC BY license

(https://creativecommons.org/licenses/by/4.0/).

\begin{abstract}
This study aimed to determine the level of academic performance of college students in relation to their level of social media exposure. The descriptive-correlational research design was used. The study was conducted during the First Semester of 2018-2019 in CapSU Dayao Satellite College utilizing the 186 randomly selected $4^{\text {th }}$-year college students from the four curricular (4) programs. A researcher-made questionnaire was utilized. Gathered data were analyzed and interpreted using mean, standard deviation, $t$-test, One-way ANOVA, and Pearson $r$. Results revealed that the respondents were 18-20 years old age, females, and with family income below the poverty threshold level. Respondents' level of social media exposure is "sometimes" and their academic performance is "good." Further, no significant difference was found in the level of social media exposure when grouped according to sex and monthly income, however, a significant difference was found when grouped according to age. On the other hand, no significant difference was found in the respondents' academic performance when grouped according to age, sex, and monthly family income. Further, no significant association or relationship was found between the level of social media exposure and the academic performance of the respondents. This implies that even though the respondents were exposed to social media they were able to maintain a good academic performance. Therefore, the time spent by students on the different social media platforms or the number of gadgets used is not indicative and determinant of how they will perform in their academics as a whole.
\end{abstract}

Keywords-academic performance, social media exposure, social media platforms.

\section{INTRODUCTION}

The popularity gained by social media reflects significant technological breakthroughs highlighting the efficient way of creating and digital exchanging of information. It enabled people to be connected in a borderless world providing social interaction across cultures. In like manner, social media plays a significant role in the paradigm shift of educational practices, attitudes, and performance of students as it became an apparent part of day-to-day activities.

The unprecedented use of students of the different social networking sites such as Facebook, Twitter, Instagram, YouTube, gaming sites, and other blogging sites has increased exponentially as evidenced by the presence of growing consumption of smartphones, laptops, iPods, and other gadgets. The number of users of social media sites attests to how students respond to technology as it is the fastest way to share photos, videos, and statuses as well as maintaining connections and relationships.

Students keep themselves updated on the top trending issues, entertainments, games, Tik Toks, fashion icons, celebrities, and other trendsetters. Social media paved opportunities for finding a job, meeting new friends virtually, and strengthening relationships. This contemplated an increased time staying engaged in social media as they actively maintain one or more accounts in the different platforms. 
Academic performance on the other hand had undergone a massive change with social media becoming an instructional tool as its usability and accessibility among students had increased. It had also enhanced how lessons are prepared and how students respond and create their school works, activities, and performances as they have more mediums to explore and utilize.

The advantages and disadvantages of optimizing the use of social media outweigh one another as it somehow affects students' performance. According to Kuppuswamy and Shankar (2010), social network websites grab the attention of the students and then divert it towards noneducational and inappropriate actions including useless chatting. Trusov, Bucklin, \& Pauwels (2009) also noted that the Internet is no doubt an evolution of technology but specifically social networks are extremely unsafe for teenagers, social networks have become hugely common and well-known in the past few years.

Likely, Rithhika \& Sara (2013) concluded that students are very fond of using Facebook, Twitter, YouTube, and Orkut. Paying attention to their academic progress and addressing any issues will go a long way towards keeping the negative aspects of social media from influencing their studies.

Further, Kulidtud (2017) implied that the main purpose of the students in using the internet is different from their actual activity whenever they already accessed the sites. While their common main objective of accessing the networks was for academic purposes (i.e., to communicate with people who are away from them) but in practice, they were using their internet time for social purposes (i.e., to like the post of their friends, topics and etc.). Also, Liccardi, Pau, Ounnas, \& Massey (2007) reviewed that the students are socially connected by sharing their daily learning experiences and do conversation on several topics.

Progressively, social media became a constant engagement among students. However, some students become very poor academically (Egedegbe, 2014). As ascertained by Brubaker (2013), that the current generation of college students has been exposed to a technology that led them to rely on social media such as Facebook and Twitter. It has an impact on academic performance when students overuse or multitask while doing their school work.

The Philippines being coined as the social media capital of the world where millions of Filipinos stay online for hours a day scrolling and chatting as a form of social interaction, students have become accustomed to having information at their fingertips. However, how they use their time and how they prioritize what information to access in relation to their academic performance while considering the poor internet connectivity, lack of gadgets and financial limitations of the students may be examined further. Likewise, on a personal note, diverted and unfocused attention of the students due to having gadgets and very active social media which deters them from doing assignments, studying for exams, and showing improvements in their performance was observed. Thus, interest in this study was pursued.

\subsection{Statement of the Problem}

Thus, the researcher decided to conduct this study to see if indeed the level of social media exposure of the students affects their academic performance. This study aimed to determine the level of academic performance of college students in relation to their level of social media exposure.

Specifically, it answered the following:

1. What is the socio-demographic profile of the respondents?

2. What is the level of social media exposure of the respondents?

3. What is the level of academic performance of the respondents?

4. Is there a significant difference in the level of social media exposure considering the respondent's sex, age, and monthly family income?

5. Is there a significant difference in the level of academic performance considering the respondent's sex, age, and monthly family income? and

6. Is the level of academic performance significantly related to the level of social media exposure?

\subsection{Hypotheses of the Study}

Based on the given problem, the following hypotheses were forwarded:

1. There is no significant difference in the level of social media exposure considering the respondent's sex, age, and monthly family income.

2. There is no significant difference in the level of academic performance considering the respondent's sex, age, and monthly family income.

3. The level of academic performance is not significantly related to the level of social media exposure.

\section{METHOD}

This study utilized the descriptive-correlation research design. The dependent variable in the study was the level of academic performance while the independent variables 
are sex, age, monthly family income, and level of social media exposure. The study was conducted in Capiz State University, Dayao Satellite College for the Academic Year 2018-2019.

The respondents of the study were the 186 randomly selected fourth-year college students of Capiz State University, Dayao Satellite College from the four (4) offered programs of the college namely: Bachelor of Science in Criminology, Bachelor of Elementary Education, Bachelor of Science in Fisheries and Bachelor of Science in Computer Science.

A researcher-made research instrument was used in the conduct of the study. It is composed of two parts. Part I dealt with information regarding the socio-demographic profile of the respondents including a) sex, (b) age, and (c) monthly family income. Part II was on the level of social media exposure. The responses of the respondents on the level of social media exposure was scored and interpreted using the following scoring guide:

$\begin{array}{lcl}\text { Score } & \text { Mean Interval } & \begin{array}{c}\text { Verbal Interpretati } \\ 5\end{array} \\ 4.20-5.0 & \text { Always } \\ 4 & 3.40-4.19 & \text { Often } \\ 3 & 2.60-3.39 & \text { Sometimes } \\ 2 & 1.80-2.59 & \text { Rarely } \\ 1 & 1.0-1.79 & \text { Never }\end{array}$

Secondary data was used for the General Weighted Average of the respondents. The source was the Transcript of Records requested by students and their Grade Online System accessible to students through their individualized passwords. The academic performance was scored based on the Revised Student Handbook (2018) of the university:

$\begin{array}{lll}\begin{array}{l}\text { Numerical } \\ \text { Grade }\end{array} & \begin{array}{l}\text { Percent } \\ \text { Equivalent }\end{array} & \text { Qualitative } \\ 1.0 & 99-100 & \text { Rating } \\ 1.25 & 96-98 & \text { Highly Outstanding } \\ 1.5 & 93-95 & \text { Outstanding } \\ 1.75 & 90-92 & \text { Very Good } \\ 2.0 & 87-89 & \text { Good } \\ 2.25 & 84-86 & \text { Very Satisfactory } \\ 2.5 & 81-83 & \text { Satisfactory } \\ 2.75 & 78-80 & \text { Unsatisfactory } \\ 3.0 & 75-77 & \text { Passed } \\ 5.0 & \text { Below } 70 & \text { Failure }\end{array}$

The questionnaire was subjected to face validity or content validity by a panel composed of three members considered as experts (Stoner et al., 2011) Their suggestions and recommendations were observed in the modification of the test. Once the content was validated, the instrument was pilot tested (Daud, Khidzir, Ismail, and Abdullahto, 2018) to 30 students who are not included in the identified population. Data from the pre-test was tabulated and the reliability coefficient was computed to assure stability and consistency of the instrument (Creswell, 2010). Using Cronbach's Alpha Pallant (2001) states value above 0.6 is considered high reliability and acceptable index (Nunnally and Bernstein, 1994). Whereas, the value of Cronbach's Alpha less than 0.6 considered low. Cronbach's values in the range of 0.60 0.80 are considered moderate, but acceptable. While Cronbach's Alpha in the ranges of 0.8 and up to 1.00 is considered very good. Results were then tabulated, analyzed, and interpreted using the appropriate test statistic: mean, standard deviation, t-test, One-Way ANOVA, and Pearson r.

\section{RESULTS AND DISCUSSION}

This section presents the results of the study. Corresponding discussion, analysis, and interpretations of the data given were also discussed.

Table 1: Socio-demographic profile of the respondents

\begin{tabular}{|c|c|c|}
\hline Category & f & \multirow[t]{2}{*}{$\%$} \\
\hline Age & & \\
\hline $18-20$ & 137 & 73.7 \\
\hline $21-23$ & 40 & 21.5 \\
\hline $24-26$ & 8 & 4.3 \\
\hline $33-35$ & 1 & .5 \\
\hline Total & 186 & 100.0 \\
\hline \multicolumn{3}{|l|}{ Sex } \\
\hline Male & 80 & 43.0 \\
\hline Female & 106 & 57.0 \\
\hline Total & 186 & 100.0 \\
\hline \multicolumn{3}{|l|}{ Monthly Family Income } \\
\hline Php 5,000 \& below & 110 & 59.1 \\
\hline Php 5,001 - Php 10,000 & 38 & 20.4 \\
\hline Php 10,001 - Php 15,000 & 25 & 13.4 \\
\hline Php 15,001 - Php 20,000 & 8 & 4.3 \\
\hline Php 20,001 \& above & 5 & 2.7 \\
\hline Total & 186 & 100.0 \\
\hline \multicolumn{3}{|c|}{ Preferred Social Media Platforms } \\
\hline Facebook & 165 & 88.7 \\
\hline
\end{tabular}




\begin{tabular}{|c|r|r|}
\hline Twitter & 44 & 23.7 \\
\hline Instagram & 14 & 7.5 \\
\hline Youtube & 51 & 27.4 \\
\hline Viber & 10 & 5.4 \\
\hline Skype & 10 & 5.4 \\
\hline LinkedIn & 9 & 4.8 \\
\hline LOL & 14 & 7.5 \\
\hline Crossfire & 4 & 2.2 \\
\hline Gadgets Used & & \\
\hline Cellphone & 183 & 98.4 \\
\hline Tablet & 9 & 4.8 \\
\hline Laptop & 18 & 9.7 \\
\hline Desktop & 6 & 3.2 \\
\hline I-pod & 3 & 1.6 \\
\hline
\end{tabular}

Table 1 shows that 137 or $73 \%$ of the respondents were 18-20 years old, 106 or $57 \%$ were females, 110 or 59.1 were earning Php 5000 and below.

Further, 165 or $88 \%$ uses Facebook as their most preferred social media platform and 183 or $98.4 \%$ use a cellphone in accessing their social media.

Table 2: Social media exposure of students

\begin{tabular}{|c|c|c|c|}
\hline $\begin{array}{c}\text { Level of Media } \\
\text { Exposure }\end{array}$ & SD & Mean & $\begin{array}{c}\text { Verbal } \\
\text { Interpretation }\end{array}$ \\
\hline $\begin{array}{l}\text { Social media allows } \\
\text { me to do research } \\
\text { for my lessons / } \\
\text { assignments. }\end{array}$ & 0.98 & 3.76 & Often \\
\hline $\begin{array}{l}\text { I use social media } \\
\text { for uploading } \\
\text { pictures and videos. }\end{array}$ & 1.01 & 3.65 & Often \\
\hline $\begin{array}{l}\text { I check my social } \\
\text { media account every } \\
\text { day. }\end{array}$ & 1.13 & 3.64 & Often \\
\hline $\begin{array}{l}\text { Social media } \\
\text { updates me of my } \\
\text { friends and family's } \\
\text { activities. }\end{array}$ & 1.01 & 3.59 & Often \\
\hline $\begin{array}{l}\text { Social media } \\
\text { increases my ability } \\
\text { to communicate. }\end{array}$ & 1.00 & 3.50 & Often \\
\hline $\begin{array}{l}\text { Social media allows } \\
\text { me to make more } \\
\text { friends. }\end{array}$ & 0.96 & 3.45 & Often \\
\hline
\end{tabular}

- I spend more than

three hours

using/accessing my social media account.

- Social media is a \begin{tabular}{|l|l|l}
\hline 1.04 & 3.32 & Sometimes
\end{tabular} distraction to release boredom

- I use social media \begin{tabular}{|l|l|l}
0.92 & 3.24 & Sometimes
\end{tabular} because it allows me to reinvent myself

- Social media is a \begin{tabular}{l|l|r|}
\hline 0.86 & 3.39 & Sometimes \\
\hline
\end{tabular} venue for interactive discussion.

- $\quad$ Social media \begin{tabular}{l|l|l}
\hline 0.96 & 3.19 & Sometimes
\end{tabular} enriches my vocabulary.

- I see my social \begin{tabular}{l|l|l}
\hline 1.05 & 3.10 & Sometimes
\end{tabular} media account as a venue for releasing my school pressure and stress.

- $\quad$ Social media affects

\begin{tabular}{|l|l|l}
\hline 1.09 & 3.10 & Sometimes
\end{tabular} my spelling proficiency.

- I use social media to express myself in any way I want.

- $\quad$ Social media affects my communication skills.

- I see to it that each account is updated daily.

- Social media

\begin{tabular}{|l|l|l}
\hline 0.99 & 2.97 & Sometimes \\
\hline
\end{tabular} eliminates the need for the physical presence of a friend.

- Because of social medias I sometimes forgot $/ \mathrm{missed}$ making assignments and other school tasks.

- I do not update my $1.04 \quad 2.95$ Sometimes social media account/s regularly. 


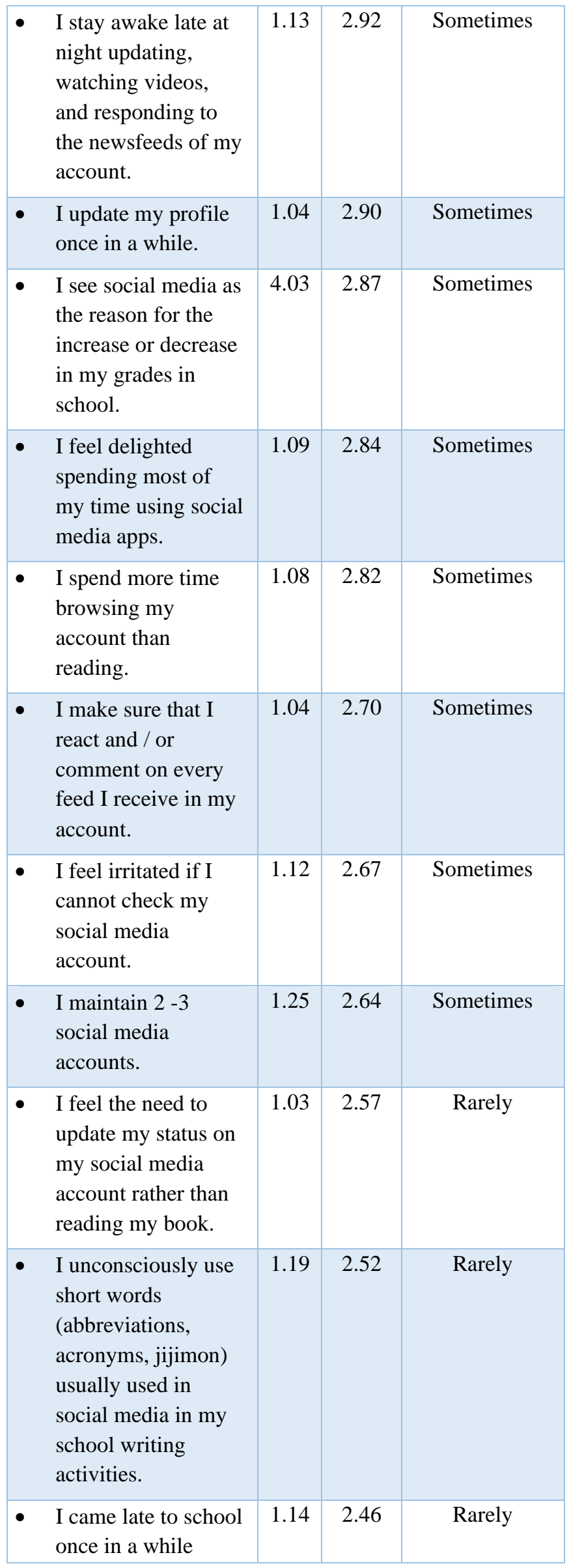

\begin{tabular}{|c|c|c|c|}
\hline $\begin{array}{l}\text { because I slept late } \\
\text { accessing my social } \\
\text { media account/s. }\end{array}$ & & & \\
\hline Overall Mean & $\mathbf{1 . 0 7}$ & $\mathbf{3 . 0 7}$ & Sometimes \\
\hline
\end{tabular}

Table 2 reflects the overall mean of the social media exposure of students. It has a grand mean of 3.07 verbally interpreted as "sometimes." The highest statement with a mean of 3.75 was on "Social media allows me to do research for my lessons/assignments."

The results reveal that students exhibit a sense of discipline and awareness of how access to social media can enhance their capability to cope with their school works. It fortifies the belief that students have developed a conscious decision making on optimizing the advantages gained through social media access to make their academic performance better.

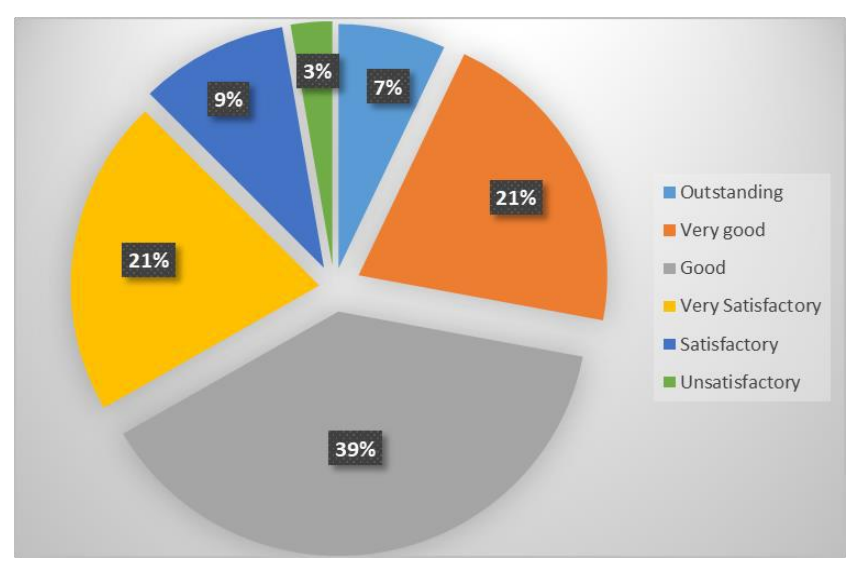

Fig.1: Level of Academic Performance

Fig. 1 discloses that the level of academic performance is Good with 78 or $39 \%$ of the respondents garnering a grade of 2 with a percent equivalent of 87-89.

The results imply that students were performing favorably towards their academics with only a handful hitting the unsatisfactory range. This suggests that students are informed of their academic responsibilities and have purposely responded towards a positive outcome in their study. However, it could also be highlighted that none were able to hit the Excellent and Highly Outstanding marks which suggest that a more intensive intervention to increase academic performance is needed. 
Table 3: Difference in the social media exposure grouped according to sex

\begin{tabular}{|l|c|c|c|c|}
\hline Category & Mean & $\begin{array}{c}\text { t- } \\
\text { value }\end{array}$ & df & $\begin{array}{c}\text { Significance } \\
\text { (2-tailed) }\end{array}$ \\
\cline { 1 - 2 } Sex & & & & \\
\cline { 1 - 2 } Male & 3.12 & \multirow{2}{*}{0.90} & 181 & 0.37 \\
\cline { 1 - 2 } Female & 3.04 & & & \\
\hline
\end{tabular}

Table 3 reveals that when respondents were grouped according to sex, the significant t-value of 1.37 on the academic performance considering respondents' sex had a significant value of 0.37 which was higher than 0.5 alpha. This implies that regardless of sex, male and female have the same level of social media exposure. It further connotes that students have been exposed to the same type of social media and probably share the same kind of interest and follow the same trends and practices as they access and use the different sites.

Table 4: Difference in the social media exposure grouped

\begin{tabular}{|c|c|c|c|c|c|c|}
\hline Variable & \begin{tabular}{|l|} 
Source of \\
Variation \\
\end{tabular} & $\begin{array}{l}\text { Sum of } \\
\text { Squares }\end{array}$ & Df & $\begin{array}{c}\text { Mean } \\
\text { Squares }\end{array}$ & $\mathbf{F}$ & Sig. \\
\hline \multirow{3}{*}{ Age } & \begin{tabular}{|l} 
Between \\
Groups \\
\end{tabular} & 6.478 & 9 & 0.720 & \multirow{3}{*}{2.100} & \multirow{3}{*}{0.032} \\
\hline & \begin{tabular}{|l|} 
Within \\
Groups
\end{tabular} & 60.327 & 176 & 0.343 & & \\
\hline & Total & 66.805 & 185 & & & \\
\hline \multirow{3}{*}{$\begin{array}{l}\text { Monthly Family } \\
\text { Income }\end{array}$} & \begin{tabular}{|l} 
Between \\
Groups \\
\end{tabular} & 0.555 & 4 & 0.139 & \multirow{3}{*}{0.379} & \multirow{3}{*}{0.824} \\
\hline & \begin{tabular}{|l|} 
Within \\
Groups \\
\end{tabular} & 66.25 & 181 & 0.366 & & \\
\hline & Total & 66.805 & 185 & & & \\
\hline
\end{tabular}

according to age and monthly family income.

$* * * \mathrm{p}<.05$

Table 4 shows that there was a significant difference in the level of social media exposure when classified according to age $(\mathrm{F}=2.100, \mathrm{p}=0.032)$ because the significant value was lower than 0.05 alpha. Meanwhile, no significant difference was found when respondents were grouped according to monthly family income $(\mathrm{F}=$ $0.379, \mathrm{p}=0.824$ ) since the significant value was higher than 0.05 alpha. Thus, the null hypothesis was accepted.

The data implies that age affects social media exposure as younger students in the age range of 18-20 access social media more than the higher age brackets. The result is supported by Lennon, Rentfro, and Curran (2012) as cited by Kulidtud (2017) presented that young adults whose ages range from 18 - 20 oftentimes use social networking sites compared to those belonging to the higher age brackets.
Table 5: Difference in the academic performance grouped according to sex.

\begin{tabular}{|l|c|c|c|c|}
\hline Category & Mean & $\begin{array}{c}\text { t- } \\
\text { value }\end{array}$ & df & $\begin{array}{c}\text { Significance } \\
\text { (2-tailed) }\end{array}$ \\
\cline { 1 - 2 } Sex & \multirow{2}{*}{1.37} & \multirow{2}{*}{181} & 0.17 \\
\cline { 1 - 2 } Male & 2.13 & & \\
\hline
\end{tabular}

Table 5 shows that when respondents were grouped according to sex, the significant t-value of 1.37 on the academic performance considering respondents' sex had a significant value of 0.17 which was higher than 0.5 alpha. Thus, the null hypothesis was accepted. This implies regardless of sex, male and female students gave out the same level of academic performance.

Table 6: Difference in the academic performance grouped according to age and monthly family income.

\begin{tabular}{|c|c|c|c|c|c|c|}
\hline Variable & $\begin{array}{l}\text { Source of } \\
\text { Variation }\end{array}$ & $\begin{array}{c}\text { Sum of } \\
\text { Squares }\end{array}$ & Df & $\begin{array}{c}\text { Mean } \\
\text { Squares }\end{array}$ & $\mathbf{F}$ & Sig. \\
\hline \multirow{3}{*}{ Age } & $\begin{array}{l}\text { Between } \\
\text { Groups }\end{array}$ & 0.481 & 9 & 0.053 & \multirow{3}{*}{0.673} & \multirow{3}{*}{0.733} \\
\hline & \begin{tabular}{|l} 
Within \\
Groups
\end{tabular} & 13.99 & 176 & 0.079 & & \\
\hline & Total & 14.472 & 185 & & & \\
\hline \multirow{3}{*}{$\begin{array}{l}\text { Monthly Family } \\
\text { Income }\end{array}$} & $\begin{array}{l}\text { Between } \\
\text { Groups }\end{array}$ & 0.134 & 4 & 0.033 & \multirow{3}{*}{0.422} & \multirow{3}{*}{0.793} \\
\hline & $\begin{array}{l}\text { Within } \\
\text { Groups }\end{array}$ & 14.338 & 181 & 0.079 & & \\
\hline & Total & 14.472 & 185 & & & \\
\hline
\end{tabular}

Table 6 discloses that no significant difference was found when respondents were grouped according to age ( $\mathrm{F}$ $=0.673, \mathrm{p}=0.733)$ and monthly family income $(\mathrm{F}=$ $0.422, \mathrm{p}=0.793$ ) since the significant value was higher than 0.05 alpha. Thus, the null hypothesis was accepted. Results signify that regardless of the age and monthly family income of the students, the academic performance generally is the same.

Further, results may imply that students have developed a sense of understanding of what good academic records could do to land them good jobs regardless of their age.

Also, the family income or finances of the students may have not presented a difference in the academic performance may be due to the initiatives of the school and government in extending financial support through scholarships and allowances for qualified indigents, academic, and sports achievers, and student leaders. 
Table 7: Relationship between the level of social media exposure and academic performance

\begin{tabular}{|c|c|c|c|}
\hline Pearson Correlation & $\mathbf{R}$ & $\mathbf{r}^{2}$ & Significance \\
\hline $\begin{array}{c}\text { Level of Social Media } \\
\text { Exposure and Level of } \\
\text { Academic Performance }\end{array}$ & 0.03 & 0.0009 & 0.68 \\
\hline
\end{tabular}

Looking at the Pearson $r$ value, no significant association between level of social media exposure and academic performance $(\mathrm{r}=0.03 ; \mathrm{p}=0.68)$ was found because the significant value was higher than 0.05 alpha. The result shows that there is a very weak positive correlation but this correlation is not significant. Thus, the null hypothesis was accepted.

Students were performing academically despite accessing social media sites. It is relevant to note that in the face of social media's popularity, students can prioritize and multi-task between academic-related researches and social interactions. Correspondingly, students have learned to manage their time and were able to maximize the advantages of using social media.

Indeed, social media has contributed greatly to facilitating learning in the 21 st century.

\section{CONCLUSIONS}

Facebook is the most highly utilized and preferred social media platform as it is the most accessible and popular among students. The cellphone is the widely available gadget used in accessing social media platforms most likely it fits the financial limitations of students.

The level of social media exposure of students is not alarmingly high and within control which led to contemplate that students are mindful of their time and reasons for accessing social media.

Academic performance reflects good performance. However, the goal for excellence is not yet addressed. Thus, an intervention plan may be designed to help increase performance, especially for board courses.

Generation Z, for ages 18-22, demonstrates adeptness and familiarity with social media's uses and applications which allowed them to navigate sites and determine relevant information for academic and social purposes.

Provisions for social media as an educational tool for teachers and students may be explored. Advantages and disadvantages maybe weighed so countermeasures and guidelines may be established for the improvement of academic performance.
To further enhance academic performance, the administration may address the following implications:

7. The conduct of seminars or conferences in media and information literacy may be included to strengthen student's capability and knowledge in the responsible use of digital information, assert their rights and protect them from cyberbullying.

8. Considerations for an Enhanced Faculty Development Plan may be given prior attention. Send faculty to seminars and training, fellowships, and scholarship grants with a focus on internationalization for continuous development and upgrading of their pedagogical skills based on the newest trends in teaching.

\section{ACKNOWLEDGMENT}

The author would like to express her heartfelt gratitude to the top management of Capiz State University headed by Dr. Editha C. Alfon and Dr. Efren Linan, VP-Research Development and Extension for the support in the conduct, presentation, and publication of this research work. The same appreciation is afforded to her colleagues and students of CapSU - Dayao Satellite College for the utmost response and assistance in the development and accomplishment of this study.

\section{REFERENCES}

[1] Brubaker, E. (2013). The relationship between facebook activity and academic performance among African American students. Liberty University, Lynchburg, VA, pp 30 and 22.

[2] Creswell, J.W. (2005), Educational research - planning, conducting, and evaluating quantitative and qualitative research, (3rd Ed.), Pearson Merril Prentice Hall, New Jersey.

[3] Creswell, J.W. (2010), Educational research - planning, conducting, and evaluating quantitative and qualitative research, (4th Ed.), Pearson Merril Prentice Hall, New Jersey

[4] Curran, J, \& Lennon, R. (2011). Participating in the Conversation: Exploring adoption of Online Social Media Networks. Academy of Marketing Studies Journal 15(1), 21 38.

[5] Daud, KA, Khidzir, NZ, Ismail, AR and Abdullah, FA. (2018). Validity and reliability of instrument to measure social media skills among small and medium entrepreneurs at Pengkalan Datu River. International Journal of Development and Sustainability, 7(3), pp.1036-1037

[6] Egedegbe, N. (2014). Academic performance in Girne American university. North Cyprus. pp. 1-11.

[7] Kulidtod, R. (2017). Effects of social networking media to the academic performance of the students. Advances in 
Economics, Business and Management Research, Volume 45

[8] Kuppuswamy, S. \& Shankar, N. (2010). The impact of social networking websites on the education of youth. https://doi.org/10.4018/jvcsn.2010010105

[9] Liccardi, I., Pau, R., Ounnas, A. \& Massey, E. (2007). The role of social networks in students' learning experiences. https://doi.org/10.1145/1345375.1345442

[10] Nunnally, J.C. and Bernstein, I.R. (1994), Psychometric theory, Ed. ke-3, McGraw-Hill, New York.

[11] Pallant, J. (2001), SPSS survival manual - a step by step guide to data analysis using SPSS for windows (version 10), Buckingham Open University Press.

[12] Trusov, M., Bucklin, R.E., \& Pauwels, K. (2009). Effects of word-of-mouth versus traditional marketing: Findings from an internet social networking site. Journal of Marketing Vol. 73, Issue 5, 2009. https://doi.org/10.1509/jmkg.73.5.90

[13] Stoner, J., Perrewe, P.L. and Hofacker, C. (2011), "The development and validation of the multidimensional identification scale", Journal of Applied Social Psychology, Vol. 41 No. 7, pp. 1632-1658 